ISSN (E): 2277 - 7695

ISSN (P): 2349-8242

NAAS Rating: $\mathbf{5 . 2 3}$

TPI 2021; 10(1): 739-744

(C) $2021 \mathrm{TPI}$

www.thepharmajournal.com

Received: 03-11-2020

Accepted: 07-12-2020

\section{Mamta Phogat}

Department of Soil Science, CCS Haryana Agricultural

University, Hisar, Haryana,

India

\section{Rita Dahiya}

Department of Physics,

CCS Haryana Agricultural

University, Hisar, Haryana,

India

\section{PS Sangwan}

Department of Soil Science, CCS Haryana Agricultural

University, Hisar, Haryana, India

\section{SK Kakraliya}

Central Soil Salinity Research Institute, Karnal, Haryana, India

\section{Vishal Goyal}

Department of Soil Science, CCS Haryana Agricultural

University, Hisar, Haryana, India

\section{Santhosh Kumar}

Department of Soil Science, CCS Haryana Agricultural University, Hisar, Haryana, India

\section{Sunil Kumar}

Department of Soil Science \& Agricultural Chemistry, Swami Keshwanand Rajasthan Agriculture University, Bikaner, Rajasthan, India

\section{Corresponding Author:} Mamta Phogat Department of Soil Science, CCS Haryana Agricultural University, Hisar, Haryana, India

\section{Effect of long term zero tillage and different moisture regimes on NPK uptake by wheat in legume based cropping systems of north-western Indo-gangetic plains}

\author{
Mamta Phogat, Rita Dahiya, PS Sangwan, SK Kakraliya, Vishal Goyal, M \\ Santhosh Kumar and Sunil Kumar
}

DOI: $\underline{\text { https://doi.org/10.22271/tpi.2021.v10.i1j.5870 }}$

\begin{abstract}
A field experiment "Effect of long term zero tillage and different moisture regimes on NPK uptake by wheat in legume based cropping systems of north-western Indo-Gangetic Plains" was conducted during 2017-18 and 2018-19 on an on-going long term experiment on 'Effect of varying moisture regimes in zero-till wheat succeeding mungbean and sorghum' since 2006 at, CCS HAU, Hisar. The experiments consisted of two cropping systems (mungbean-wheat, MW and sorghum-wheat, SW), three tillage practices viz. CT-CT (conventional tillage in both kharif \& rabi seasons), CT-ZT (conventional tillage in kharif \& zero tillage in rabi seasons) and ZT-ZT (zero tillage in both kharif \& rabi seasons); and three moisture regimes $\{\mathrm{IW} / \mathrm{CPE}=0.60(\mathrm{M} 0.60), 0.75(\mathrm{M} 0.75)$ and $0.90(\mathrm{M} 0.90)\}$. The adoption of ZT-ZT practice increased uptake of nitrogen, phosphorus and potassium as compared to CT-ZT and CT-CT practices in all the moisture regimes under mungbean-wheat and sorghum-wheat cropping systems. The uptake of nitrogen was significantly higher in mungbean-wheat cropping system (41.83 and $57.21 \%)$ as compared to sorghum-wheat cropping system by grain and straw, respectively. It was significantly highest in ZT-ZT (109.44 and 99.46; 156.91 and 117.34\%) as compared to CT-CT over all the moisture regimes under mungbean-wheat and sorghum-wheat cropping systems by grain and straw, respectively. In present study, uptake of nitrogen was significantly highest at M0.90 (36.79 and 17.84; and 49.68 and $24.43 \%$ ) as compared to M0.60 over all the tillage practices in mungbean-wheat and sorghum-wheat cropping systems by grain and straw, respectively. The similar trends were observed for uptake of phosphorus and potassium by the wheat grain and straw. Therefore long term zero tillage with inclusion of legumes can be a promising alternative to sustainably increase uptake of nutrients in soil for cerealcereal cropping systems which ultimately plays a pivotal role to sustain the crop productivity and optimum ecosystem functioning with improving soil health.
\end{abstract}

Keywords: Zero tillage, moisture regimes, legumes, soil health, sustainability, nutrient uptake

\section{Introduction}

Due to conventional production practises, the sustainability of cereal-cereal cultivation systems in the IGP of India is at risk. In the beginning zero tillage practice was aimed to conserve soil, water, to reduce cost of production (Holland 2004). Beyond this, the practice has multiple benefits in increasing the overall system performance (Kakraliya et al. 2018) ${ }^{[19]}$. In recent years, water, energy and labour scarcity, the increasing production costs, decreasing farm profitability and variability caused by climate change are major challenges facing farmers in India's Indo-Gangetic Plains (IGP). Wheat is India's second most important cereal crop after rice, occupying an area of 31.2 million ha and producing 95.8 million tonnes. For better crop production, the common perception among farmers is to plough the soil 2-3 times after harvesting the rainy season crops. This has, however, contributed to the growth of hard-pan and low efficiency of input use (Das et al. 2014) ${ }^{[6]}$. Therefore, conventional production practises need to be enhanced or replaced with resource-conserving technologies (RCTs) by repeated ploughing adopted in wheat under the rice-wheat or maize-wheat cropping system to adapt to evolving climate changes and to increase productivity and farm profitability and soil health on a sustainable basis (Ladha et al. 2014) ${ }^{[22]}$. 
It's necessary to increase crop production on a sustainable basis while keeping resources like the environment and our resources for food sources. In India, the cradle of the Green Revolution, the Indo-Gangetic Plains (IGP) covers about $20 \%$ and $27 \%$ of the total geographical and net cultivated area, respectively, and produces about half of the food consumed in the country (Dhillon et al., 2010, Das et al., 2018) ${ }^{[9]}$. By 2050 , the world's population will be over 9 billion and $37 \%$ will live in China and India, requiring an expected $59 \%$ to $98 \%$ increase in food demand, putting more pressure on natural resources. India will have to double its cereal production to feed the 1.6 billion people of India by 2050 (Swaminathan and Bhavani, 2013) ${ }^{[30]}$. The challenge is to reach this aim with less resources and with a lower environmental footprint while buffering the risks of climate variability to ensure long-term sustainability. Over the next 50 years, five of the top ten issues facing humanity (i.e. food, electricity, water, the atmosphere and poverty) are directly linked to soil health. The growing concern for food security by improved soil management practises therefore calls for the adoption of conservation agriculture. Conservation agriculture is a resource-saving system for agricultural crop production that, in this era of climate change, aims to offer equal benefits along with high and sustainable levels of production while at the same time protecting the environment (FAO, 2010) ${ }^{[14]}$. Several studies have shown that we can increase the nutrient uptake by crops by introducing zero tillage systems (Powlson et al. 2012) [26]. Zero tillage method has major effect on nutrient availability to the crops and uptake by the plants. In zero tillage, nutrients near the soil surface increased and hence uptake by plants also increased (Bhatt et al., 2016) ${ }^{[2]}$. In the literature, there's far less attention given to the effect of tillage on plant nutrient uptake as compared to other properties of soil. Tillage increases the decomposition of crop residues because it facilitates nutrient supply and enables closer interaction between plant tissue and soil aggregate surfaces, the primary biome of soil microbes (Bronick and Lal $2005)^{[3]}$. In addition, avoiding soil disturbance in zero tillage protect the soils and improve the preservation of carbon, thereby increasing availability and uptake of essential nutrients in the soil (Corbeels et al. 2006) ${ }^{[5]}$. Sustainable intensification of cereal (rice/maize/pearlmillet) systems focused on conservation agriculture (CA) integrated with mungbean enhanced soil organic carbon and chemical properties (Choudhary et al., 2018) ${ }^{[4]}$. Legumes with their inherent characteristics such as leaf dropping, deep root, biological $\mathrm{N}$ fixation, and greater root exudate release enhance soil health (Hazra et al., 2018; Kakraliya et al. 2018a) ${ }^{[16,18]}$. In wheat after mungbean, the enhanced carbon and other nutrient concentration improve the soil's overall consistency (Singh et al. 2015). The inclusion of legumes in cereal-cereal rotation shifts the balance of nutrient inputoutput, nutrient and carbon input through non-harvested crop residues (root carbon) that are likely to impact long-term productivity (Hazra et al., 2014) ${ }^{[17]}$. The use of legume crops and zero tillage systems has been shown to greatly reduce the risk of soil erosion (Lentz and Bjorneberg, 2003) ${ }^{[23]}$. Good soil health plays a pivotal role to sustain the crop productivity and optimum ecosystem functioning. Improved soil aggregation and higher soil organic carbon (SOC) stock are the essential components of good soil health (Denef et al., 2001) ${ }^{[10]}$. In fact, land use pattern and crop management practices have a differential influence on soil carbon and aggregate dynamics (Pinheiro et al., 2004) ${ }^{[25]}$. The rate of $\mathrm{N}$ and $\mathrm{P}$ uptake by wheat, sown after pearl millet was significantly at par to each other and significantly higher than that of pearl millet, sown after cowpea and cluster bean (Singh et al., 2003) ${ }^{[28]}$. The $\mathrm{N}$ uptake was higher by 16.7 and 13.1 percent and $\mathrm{P}$ uptake by 22.2 and 16.5 percent when cowpea and cluster bean were grown after wheat, respectively, compared to pearl millet. In the research conducted by Balyan (1997) ${ }^{[1]}$, wheat grown after legume crop either alone or as an intercrop during kharif was observed to have higher $\mathrm{N}$ uptake than wheat grown after pearl millet alone. Irrigation scheduling based on IW/CPE improved nitrogen absorption by grains. According to Singh and Singh (2001) ${ }^{[29]}$, the higher content of nitrogen in the treatment resulted in lower protein. The amount of the nutrient absorption by crops increased with the rise in the irrigations (Dhindwal et al., 1993) ${ }^{[12]}$. Therefore, locationspecific management practices are required in tillage and residue management practicessuitable to varying soils, crops, and climatic conditions.

Our study goal was to research how nutrient uptake in wheat is affected by long term zero tillage and different moisture regimes in cereal-cereal based cropping systems of northwestern Indo-Gangetic Plains. In evaluating its suitability for crop production, the properties of a soil play a significant role. Properties of soil including support strength, soil air space or root penetration, microbial properties, nutrient availability, nutrient uptake and water use efficiency are all closely connected with each other. There is a lot of literature available on the impact of zero tillage practises on soil chemical properties but there is little knowledge on the combined effect of zero tillage adoption and the introduction of legumes into the cropping system and moisture regimes on chemical properties of soil in various cropping systems. It was hypothesised that, for a few uninterrupted years, the adoption of zero tillage in the agricultural production system in general and in wheat, particularly with different crop rotations, might significantly improve the soil macro- and micronutrient, eventually affecting sustainability of the system. The present investigation was therefore conducted to tackle this issue.

\section{Material and Methods \\ Study site characteristics}

The present investigation was carried out at an on-going longterm experiment at Soil Research Farm, Department of Soil Science, CCS HAU, Hisar. The coordinates of the experimental site is $29.10^{\circ} \mathrm{N}, 75.46^{\circ} \mathrm{E}$ and at an altitude of 215.2 meters above mean sea level. The experimental soil was sandy loam (71.5\% sand, $9.3 \%$ silt and $19.2 \%$ clay) and classified as Typic Haplustepts. The experimental soil was slightly alkaline, low in organic carbon content, low in available nitrogen, medium in available phosphorus and high in available potassium (Kumar, 2008) ${ }^{[21]}$. The experimental site has a semi-arid climate with hot and dry summer and extremely cold winter. The mean monthly maximum and minimum temperature show a wide range of fluctuations during summer as well as winter seasons. The mean maximum and minimum temperature was $39.0{ }^{\circ} \mathrm{C}$ in May, 2018 and $12.4{ }^{\circ} \mathrm{C}$ in January, 2018 and $42.2{ }^{\circ} \mathrm{C}$ in May 2019 and $13.0{ }^{\circ} \mathrm{C}$ in February, 2019, respectively. Total rainfall received during study period was $29.9 \mathrm{~mm}$ and $44.1 \mathrm{~mm}$ from November, 2017 to April, 2018 and November, 2018 to April, 2019 , respectively.

\section{Treatments and experimental design}

The experiment was carried out with two main-plot treatments, viz. (i) Mungbean-wheat and, (ii) Sorghum-wheat 
cropping systems and with three sub-plot treatments viz. (i) Conventional tillage in both kharif \& rabi seasons, (ii) conventional tillage in kharif \& zero tillage in rabi seasons and, (iii) zero tillage in both kharif \& rabi along with three sub-sub-plot treatments of soil moisture regimes viz, IW/CPE of $0.60,0.75 \& 0.90$. The experimental design was split-splitplot and replicated thrice in CT-CT plots, the fields were ploughed during both kharif and rabi seasons. In CT-ZT plots, the fields were ploughed during kharif only and no tillage was done during rabi season. In ZT- ZT plots, no tillage was done during both the kharif and rabi seasons. In CT practice, the residues of the preceding crop i.e. wheat/mungbean/sorghum were manually removed, and seed bed tilth for wheat/mungbean/sorghum was prepared by two disc to about $10 \mathrm{~cm}$ followed by planking (leveling with a $3 \mathrm{~m}$ long wooden block) of the fields. In plots with ZT practice, the crop was harvested and no tillage was done for preparation of seed bed for the succeeding crop, and crop was sown with zero till machine. The wheat (WH 1105) was sown on November 23, 2017 during 2017-18 and on November 25, 2018 during 2018-19. The wheat was harvested on 25 April 2018 during 2017-18 and on 24 April 2019 during 2018-19.

\section{Measurement for uptake of nutrients by the Crop}

The uptake of macro nutrients $(\mathrm{N}, \mathrm{P}, \mathrm{K})$ by the grain and straw of the wheat crop for both the years i.e. 2017-18 and 2018-19 (data has been showed as pooled of both years in results) was obtained by multiplying the nutrient concentration in grain and straw with their respective yield using the following formula:

Nutrient uptake $(\mathrm{kg}$ ha-1) = Nutrient concentration in grain/straw $(\%) \times$ grain/straw yield $(\mathrm{kg}$ ha- 1$) / 100$

\section{Statistical analysis}

Data were exposed to analysis of variance for split-split plot design to know the significant difference among the treatments. Least significant difference values were used to compare the treatment means at $\mathrm{p}=0.05$ using OPSTAT software (Sheoran et al., 1998) ${ }^{[27] .}$

\section{Results and Discussion \\ Nitrogen uptake}

Uptake of nitrogen by wheat grain and straw affected by long term zero tillage in wheat under different moisture regimes in mungbean-wheat and sorghum-wheat cropping systems are presented in Table 1. The continuous adoption of ZT-ZT practice for twelve years increased uptake of nitrogen as compared to CT-ZT and CT-CT practices in all the moisture regimes under mungbean-wheat and sorghum-wheat cropping systems. The uptake of nitrogen was significantly higher in mungbean-wheat cropping system (41.83 and 57.21\%) as compared to sorghum-wheat cropping system by grain and straw, respectively. It was significantly higher in ZT-ZT (109.44 and 99.46; 156.91 and $117.34 \%)$ and CT-ZT (64.64 and 47.24 and 45.18 and $24.43 \%$ ) as compared to CT-CT over all the moisture regimes under mungbean-wheat and sorghum-wheat cropping systems by grain and straw, respectively. In present study, uptake of nitrogen was significantly higher at $\mathrm{M}_{0.90}$ (36.79 and 17.84; and 49.68 and $24.43 \%$ ) and $\mathrm{M}_{0.75}$ (15.66 and 5.84; and 22.01 and $12.00 \%$ ) as compared to $\mathrm{M}_{0.60}$ over all the tillage practices in mungbeanwheat and sorghum-wheat cropping systems by grain and straw, respectively. The uptake of nitrogen by grain was higher as compared to the wheat straw. The interactive effects of cropping system and tillage; cropping system and moisture regimes; tillage and moisture regimes; and cropping system, tillage and moisture regimes was observed significant for nitrogen uptake by wheat grain and straw. This higher uptake of nitrogen by wheat grain and straw occurred due to more availability of nutrients, as a result grain and straw yield was higher and consequently nitrogen uptake was increased under zero tillage. More crop residues under zero tillage caused high soil organic matter and favourable soil environmental conditions. Higher moisture regimes and legume based cropping system had more organic matter; therefore, more nitrogen uptake was in case of mungbean-wheat cropping system as compared to sorghum-wheat cropping system. These results are in accord with the findings of Gupta and Seth (2007) ${ }^{[15]}$. More organic residues on the surface caused more root growth and resulted in increased uptake of nutrients by crops (Thiagalingam et al., 1991) ${ }^{[31]}$. These results are in agreement with the results of Dwivedi and Thakur (2000) ${ }^{[13]}$. The nutrient uptake by crop increased with the increase moisture regimes mainly owing to higher yield (Dhindwal et $a l ., 1993)^{[12]}$. The increase in nitrogen uptake was more due to higher yield under zero tillage and in mungbean-wheat system at higher moisture regimes and the results is consistent with the results of Singh et al. (2003) ${ }^{[28]}$ and Kumar et al. (2000) ${ }^{[20]}$.

Table 1: Effect of long-term zero tillage on nitrogen uptake $\left(\mathrm{kg} \mathrm{ha}^{-1}\right)$ by grain and straw at different moisture regimes under mungbean-wheat and sorghum-wheat cropping systems

\begin{tabular}{|c|c|c|c|c|c|c|c|c|}
\hline \multirow{2}{*}{ Moisture Regime (IW/CPE) } & \multicolumn{3}{|c|}{ Sorghum-Wheat } & \multirow{2}{*}{ Mean } & \multicolumn{3}{|c|}{ Mungbean-Wheat } & \multirow{2}{*}{ Mean } \\
\hline & CT-CT & CT-ZT & ZT-ZT & & CT-CT & CT-ZT & ZT-ZT & \\
\hline \multicolumn{9}{|c|}{ Grain } \\
\hline $\mathrm{M}_{0.60}$ & 100.92 & 164.68 & 235.28 & 166.96 & 140.17 & 235.02 & 277.26 & 217.48 \\
\hline $\mathrm{M}_{0.75}$ & 111.07 & 177.82 & 241.27 & 176.72 & 164.03 & 257.64 & 332.93 & 251.53 \\
\hline $\mathrm{M}_{0.90}$ & 150.97 & 191.91 & 247.39 & 196.76 & 180.86 & 305.92 & 405.70 & 297.50 \\
\hline Mean & 120.98 & 178.14 & 241.31 & 180.15 & 161.69 & 266.19 & 338.63 & 255.50 \\
\hline $\mathrm{CD}(\mathrm{p}=0.05)$ & \multicolumn{8}{|c|}{$\mathrm{A}=9.51, \mathrm{~B}=2.35, \mathrm{~A} \times \mathrm{B}=3.32, \mathrm{C}=3.79, \mathrm{~A} \times \mathrm{C}=5.36, \mathrm{~B} \times \mathrm{C}=6.56, \mathrm{~A} \times \mathrm{B} \times \mathrm{C}=9.28$} \\
\hline \multicolumn{9}{|c|}{ Straw } \\
\hline $\mathrm{M}_{0.60}$ & 19.78 & 24.75 & 42.98 & 29.17 & 25.62 & 39.64 & 59.26 & 41.51 \\
\hline $\mathrm{M}_{0.75}$ & 21.81 & 29.38 & 46.82 & 32.67 & 29.39 & 43.40 & 79.15 & 50.64 \\
\hline $\mathrm{M}_{0.90}$ & 24.00 & 32.13 & 52.76 & 36.30 & 37.18 & 50.79 & 98.41 & 62.13 \\
\hline Mean & 21.86 & 28.75 & 47.52 & 32.71 & 30.73 & 44.61 & 78.94 & 51.43 \\
\hline $\mathrm{CD}(\mathrm{p}=0.05)$ & \multicolumn{8}{|c|}{$\mathrm{A}=2.26, \mathrm{~B}=0.99, \mathrm{~A} \times \mathrm{B}=1.40, \mathrm{C}=0.76, \mathrm{~A} \times \mathrm{C}=1.07, \mathrm{~B} \times \mathrm{C}=1.31, \mathrm{~A} \times \mathrm{B} \times \mathrm{C}=1.85$} \\
\hline
\end{tabular}

$\mathrm{CT}=$ conventional tillage, $\mathrm{ZT}=$ zero tillage, $\mathrm{M}_{0.60}=$ moisture regime at $\mathrm{IW} / \mathrm{CPE}=0.60, \mathrm{M}_{0.75}=$ moisture regime at $\mathrm{IW} / \mathrm{CPE}=0.75, \mathrm{M}_{0.90}=$ moisture regime at $\mathrm{IW} / \mathrm{CPE}=0.90 ; \mathrm{A}=$ cropping factor, $\mathrm{B}=$ tillage factor, $\mathrm{C}=$ moisture regime factor 


\section{Phosphorus uptake}

The adoption of ZT-ZT practice increased uptake of phosphorus as compared to CT-ZT and CT-CT practices in all the moisture regimes under mungbean-wheat and sorghumwheat cropping systems (Table 2). The uptake of phosphorus was significantly higher in mungbean-wheat cropping system (44.20 and $34.37 \%$ ) as compared to sorghum-wheat cropping system by grain and straw, respectively. It was significantly higher in ZT-ZT (116.64 and 105.54; 81.72 and 58.21\%) and CT-ZT (68.10 and 55.15 and 39.75 and 26.90\%) as compared to CT-CT over all the moisture regimes under mungbeanwheat and sorghum-wheat cropping systems by grain and straw, respectively. In present study, uptake of phosphorus was significantly higher at $\mathrm{M}_{0.90}$ (33.11 and 24.19; and 24.78 and $15.95 \%$ ) and $\mathrm{M}_{0.75}$ (19.73 and 8.59; and 9.46 and $6.16 \%$ ) as compared to $\mathrm{M}_{0.60}$ over all the tillage practices in mungbean-wheat and sorghum-wheat cropping systems by grain and straw, respectively. Uptake of phosphorus by grain was significantly higher as compared to straw of wheat. The interactive effects of cropping system and tillage; cropping system and moisture regimes; tillage and moisture regimes; and cropping system, tillage and moisture regimes were found significant for phosphorus uptake by grain but interactive effects of tillage and moisture regimes; and cropping system, tillage and moisture regimes were observed non-significant by straw in wheat. This higher uptake of phosphorus by wheat grain and straw occurred due to more availability of nutrients, as a result grain and straw yield was higher and consequently phosphorus uptake was increased under zero tillage. More crop residues under zero tillage caused high soil organic matter and favourable soil environmental conditions. Higher moisture regimes and legume based cropping system had more organic matter; therefore, more phosphorus uptake was in case of mungbean-wheat cropping system as compared to sorghum-wheat cropping system. These results are in accord with the findings of Mukherjee (2008) ${ }^{[24]}$. These results are in agreement with the results of Dwivedi and Thakur (2000) ${ }^{[13]}$, and Das et al. (2001) [8]. The nutrient uptake by crop increased with the increase moisture regimes mainly owing to higher yield (Dhindwal et al., 1993) ${ }^{[12]}$. The increase in phosphorus uptake was more due to higher yield under zero tillage and in mungbean-wheat system at higher moisture regimes and these results is consistent with the results of Singh et al. (2003) ${ }^{[28]}$.

Table 2: Effect of long-term zero tillage on phosphorus uptake $\left(\mathrm{kg} \mathrm{ha}^{-1}\right)$ by grain and straw at different moisture regimes under mungbean-wheat and sorghum-wheat cropping systems

\begin{tabular}{|c|c|c|c|c|c|c|c|c|}
\hline \multirow{2}{*}{ Moisture Regime (IW/CPE) } & \multicolumn{3}{|c|}{ Sorghum-Wheat } & \multirow{2}{*}{ Mean } & \multicolumn{3}{|c|}{ Mungbean-Wheat } & \multirow{2}{*}{ Mean } \\
\hline & CT-CT & CT-ZT & ZT-ZT & & CT-CT & CT-ZT & ZT-ZT & \\
\hline \multicolumn{9}{|c|}{ Grain } \\
\hline $\mathrm{M}_{0.60}$ & 8.81 & 14.90 & 20.75 & 14.82 & 12.60 & 21.20 & 26.65 & 20.15 \\
\hline $\mathbf{M}_{0.75}$ & 9.33 & 16.40 & 22.54 & 16.09 & 14.20 & 25.35 & 32.83 & 24.13 \\
\hline $\mathrm{M}_{0.90}$ & 14.25 & 17.66 & 23.29 & 18.40 & 17.20 & 27.42 & 35.85 & 26.82 \\
\hline Mean & 10.80 & 16.32 & 22.19 & 16.44 & 14.67 & 24.66 & 31.78 & 23.70 \\
\hline \multirow{2}{*}{\multicolumn{9}{|c|}{$\begin{array}{c}\mathrm{A}=1.17, \mathrm{~B}=0.50, \mathrm{~A} \times \mathrm{B}=0.71, \mathrm{C}=0.43, \mathrm{~A} \times \mathrm{C}=0.61, \mathrm{~B} \times \mathrm{C}=0.75, \mathrm{~A} \times \mathrm{B} \times \mathrm{C}=1.06 \\
\text { Straw }\end{array}$}} \\
\hline & & & & & & & & \\
\hline $\mathrm{M}_{0.60}$ & 4.02 & 5.14 & 6.63 & 5.26 & 4.72 & 6.75 & 8.97 & 6.81 \\
\hline $\mathrm{M}_{0.75}$ & 4.24 & 5.61 & 6.91 & 5.59 & 5.29 & 7.33 & 9.76 & 7.46 \\
\hline $\mathrm{M}_{0.90}$ & 4.94 & 6.01 & 7.35 & 6.10 & 6.20 & 8.58 & 10.73 & 8.50 \\
\hline Mean & 4.40 & 5.59 & 6.96 & 5.65 & 5.40 & 7.55 & 9.82 & 7.59 \\
\hline $\mathrm{CD}(\mathrm{p}=0.05)$ & \multicolumn{8}{|c|}{$\mathrm{A}=0.144, \mathrm{~B}=0.051, \mathrm{~A} \times \mathrm{B}=0.072, \mathrm{C}=0.118, \mathrm{~A} \times \mathrm{C}=0.167, \mathrm{~B} \times \mathrm{C}=\mathrm{NS}, \mathrm{A} \times \mathrm{B} \times \mathrm{C}=\mathrm{NS}$} \\
\hline
\end{tabular}

$\mathrm{CT}=$ conventional tillage, $\mathrm{ZT}=$ zero tillage, $\mathrm{M}_{0.60}=$ moisture regime at $\mathrm{IW} / \mathrm{CPE}=0.60, \mathrm{M}_{0.75}=$ moisture regime at $\mathrm{IW} / \mathrm{CPE}=0.75, \mathrm{M}_{0.90}=$ moisture regime at $\mathrm{IW} / \mathrm{CPE}=0.90 ; \mathrm{A}=$ cropping factor, $\mathrm{B}=$ tillage factor, $\mathrm{C}=$ moisture regime factor

\section{Potassium uptake}

Uptake of potassium by wheat grain and straw as affected by long term zero tillage in wheat under different moisture regimes in mungbean-wheat and sorghum-wheat cropping systems are presented in Table 3. Uptake of potassium was significantly higher in mungbean-wheat cropping system (20.70 and $31.37 \%$ ) as compared to sorghum-wheat cropping system by grain and straw, respectively. It was significantly higher in ZT-ZT (49.34 and 6.41; 66.79 and 26.91\%) and CTZT (23.95 and 10.43 and 20.50 and $7.84 \%$ ) as compared to CT-CT over all the moisture regimes under mungbean-wheat and sorghum-wheat cropping systems by grain and straw, respectively. In present study, uptake of potassium was significantly higher at $\mathrm{M}_{0.90}(18.65$ and 16.15 ; and 29.27 and $16.17 \%$ ) and $\mathrm{M}_{0.75}$ (10.58 and 7.75; and 7.54 and $\left.4.59 \%\right)$ as compared to $\mathrm{M}_{0.60}$ over all the tillage practices in mungbeanwheat and sorghum-wheat cropping systems by grain and straw, respectively. Uptake of potassium by grain was significantly lower as compared to straw of wheat. The interactive effects of cropping system and tillage; cropping system and moisture regimes; and cropping system were observed significant for potassium uptake by grain and straw but tillage and moisture regimes significantly affected the uptake of potassium by wheat straw not grain. This higher uptake of potassium by wheat grain and straw occurred due to more availability of nutrients, as a result grain and straw yield was higher and consequently potassium uptake was increased under zero tillage. More crop residues under zero tillage caused high soil organic matter and favourable soil environmental conditions. Higher moisture regimes and legume based cropping system had more organic matter; therefore more potassium uptake was in case of mungbeanwheat cropping system as compared to sorghum-wheat cropping system. These results are in accord with the findings of Gupta and Seth (2007) ${ }^{[15]}$ and Mukherjee (2008) ${ }^{[24]}$. The nutrient uptake by crop increased with the increase moisture regimes mainly owing to higher yield (Dhindwal et al., 1993) ${ }^{[12]}$. The increase in potassium uptake was more due to higher yield under zero tillage and in mungbean-wheat system at higher moisture regimes and these results is consistent with the results of Singh et al. (2003) ${ }^{[28]}$. 
Table 3: Effect of long-term zero tillage on potassium uptake $\left(\mathrm{kg} \mathrm{ha}^{-1}\right)$ by grain and straw at different moisture regimes under mungbean-wheat and sorghum-wheat cropping systems

\begin{tabular}{|c|c|c|c|c|c|c|c|c|}
\hline \multirow{2}{*}{ Moisture Regime (IW/CPE) } & \multicolumn{3}{|c|}{ Sorghum-Wheat } & \multirow{2}{*}{ Mean } & \multicolumn{3}{|c|}{ Mungbean-Wheat } & \multirow{2}{*}{ Mean } \\
\hline & CT-CT & CT-ZT & ZT-ZT & & CT-CT & CT-ZT & ZT-ZT & \\
\hline \multicolumn{9}{|c|}{ Grain } \\
\hline $\mathrm{M}_{0.60}$ & 17.14 & 19.33 & 25.10 & 20.52 & 19.63 & 24.68 & 28.80 & 24.37 \\
\hline $\mathrm{M}_{0.75}$ & 18.97 & 21.19 & 26.18 & 22.11 & 21.10 & 26.90 & 32.83 & 26.95 \\
\hline $\mathrm{M}_{0.90}$ & 21.60 & 23.20 & 26.71 & 23.84 & 23.75 & 28.33 & 34.66 & 28.91 \\
\hline Mean & 19.23 & 21.24 & 25.99 & 22.16 & 21.49 & 26.64 & 32.10 & 26.74 \\
\hline $\mathrm{CD}(\mathrm{p}=0.05)$ & \multicolumn{8}{|c|}{$\mathrm{A}=1.08, \mathrm{~B}=0.58, \mathrm{~A} \times \mathrm{B}=0.82, \mathrm{C}=0.45, \mathrm{~A} \times \mathrm{C}=0.63, \mathrm{~B} \times \mathrm{C}=\mathrm{NS}, \mathrm{A} \times \mathrm{B} \times \mathrm{C}=1.10$} \\
\hline \multicolumn{9}{|c|}{ Straw } \\
\hline $\mathrm{M}_{0.60}$ & 148.79 & 162.03 & 186.29 & 165.70 & 166.16 & 207.57 & 248.20 & 207.31 \\
\hline $\mathrm{M}_{0.75}$ & 157.35 & 171.79 & 190.78 & 173.31 & 176.80 & 216.67 & 275.37 & 222.95 \\
\hline $\mathrm{M}_{0.90}$ & 170.18 & 179.86 & 227.46 & 192.50 & 197.91 & 227.54 & 378.53 & 267.99 \\
\hline Mean & 158.78 & 171.23 & 201.51 & 177.17 & 180.29 & 217.26 & 300.70 & 232.75 \\
\hline $\mathrm{CD}(\mathrm{p}=0.05)$ & \multicolumn{8}{|c|}{$\mathrm{A}=6.37, \mathrm{~B}=4.06, \mathrm{~A} \times \mathrm{B}=5.75, \mathrm{C}=4.15, \mathrm{~A} \times \mathrm{C}=5.87, \mathrm{~B} \times \mathrm{C}=7.19, \mathrm{~A} \times \mathrm{B} \times \mathrm{C}=10.16$} \\
\hline
\end{tabular}

$\mathrm{CT}=$ conventional tillage, $\mathrm{ZT}=$ zero tillage, $\mathrm{M}_{0.60}=$ moisture regime at $\mathrm{IW} / \mathrm{CPE}=0.60, \mathrm{M}_{0.75}=$ moisture regime at $\mathrm{IW} / \mathrm{CPE}=0.75, \mathrm{M}_{0.90}=$ moisture regime at $\mathrm{IW} / \mathrm{CPE}=0.90 ; \mathrm{A}=$ cropping factor, $\mathrm{B}=$ tillage factor, $\mathrm{C}=$ moisture regime factor

\section{Conclusion}

The results from the present investigation concluded that long term zero tillage practices had potential to enhance nutrient uptake in wheat under mungbean-wheat and sorghum-wheat cropping systems. The results also concluded that legume based cropping system is better as compared to non-legume based cropping system at different moisture regimes in arid and semi-arid climatic conditions in sandy loam soils. Adoption of long term zero tillage in wheat and inclusion of legumes in the cropping systems would be beneficial for improving the soil health on sustainable basis and consequently NPK uptake in wheat of north-western IndoGangetic Plains.

\section{Acknowledgements}

The first author acknowledges the facilities and financial assistance provided by CCS Haryana Agricultural University, Hisar, Haryana.

\section{References}

1. Balyan JS. Production potential and nitrogen uptake by succeeding wheat (Triticum aestivum) under different cropping sequences. Indian Journal of Agronomy 1997;42:250-252.

2. Bhatt R, Kukal SS, Busari MA, Arora S, Yadav M. Sustainability issues on rice-wheat cropping system. International Soil and Water Conservation Research 2016;4:64-74.

3. Bronick CJ, Lal R. "Soil structure and management: a review," Geoderma 2005;124(1-2):3-22.

4. Choudhary Madhu, Jat Hanuman S, Datta Ashim, Yadav Arvind K, Sapkota Tek B, Mondal Sandip et al. Sustainable intensification influences soil quality, biota, and productivity in cereal-based agroecosystems. Applied Soil Ecology 2018,S0929139317313136 doi:10.1016/j.apsoil.2018.02.027.

5. Corbeels M, Scopel E, Cardoso A et al. Soil carbon storage potential of direct seeding mulch-based cropping systems in the Cerrados of Brazil. Glob Chang Biol 2006;12:1773-1787. doi:10.1111/j.1365- 2486.2006.012 33. $\mathrm{x}$

6. Das TK, Bhattacharyya R, Sudhishri S, Sharma AR, Saharawat YS, Bandyopadhyay KK et al. Conservation agriculture in an irrigated cotton-wheat system of the western Indo-Gangetic Plains: crop and water productivity and economic profitability. Field Crop Res 2014;158:24-332.
7. Das A, Ghosh PK, Lal R, Saha R, Ngachan S. Soil quality effect of conservation practices in maizerapeseed cropping system in eastern Himalaya. Land Degradation and Development 2014. DOI: 10.1002/ldr.2325.

8. Das DK, Medhi DN, Guha B. Recycling effect of crop residues with chemical fertilizers on physico-chemical properties of soil and rice (O. sativa) yield. Indian Journal of Agronomy 2001;46(4):648-653.

9. Das TK, Saharawat YS, Bhattacharyya R, Sudhishri S, Bandyopadhyay KK, Sharma AR et al. Conservation agriculture effects on crop and water productivity, profitability and soil organic carbon accumulation under a maize-wheat cropping system in the North-western Indo-Gangetic Plains. Field Crop Res 2018;215:222231.

10. Denef K, Six J, Paustian K, Merckx R. Importance of macroaggregate dynamics in controlling soil carbon stabilization: short-term effects of physical disturbance induced by dry-wet cycles. Soil Biol. Biochem 2001;33:2145-2153.

11. Dhillon BS, Kataria P, Dhillon PK. National food security vis-à-vis sustainability of agriculture in high crop productivity regions. Curr. Sci 2010;98:33-36.

12. Dhindwal AS, Jagdev Singh, Poonia SR. Irrigation needs of field crops under shallow water table conditions. In: Proc. of National Workshop on "Crop and Water Use". March 10-13, WALMI, Lucknow, India 1993.

13. Dwivedi DK, Thakur SS. Production potential of wheat (Triticum aestivum L.)crop as influenced by residual organics, direct and residual fertility levels under rice (Oryzasativa)-wheat cropping system. Indian Journal of Agronomy 2000;45(4):641-647.

14. FAO. What is conservation agriculture 2010, FAO CAwebsite http://www.fao.org/ag/ca/1a.html. Accessed on 13/08/2019.

15. Gupta R, Seth A. A review of resource conserving technologies for sustainable management of the ricewheat cropping systems of the Indo-Gangetic plains (IGP). Crop Protection 2007;26:436-447.

16. Hazra KK, Singh SS, Nath CP, Borase DN, Kumar N, Parihar AK et al. Adaptation mechanisms of winter pulses through rhizospheric modification in mild-alkaline soil. National Academy Science Letters 2018;41:193196.

17. Hazra KK, Venkatesh MS, Ghosh PK, Ganeshamurthy AN, Kumar N, Nadarajan $\mathrm{N}$ et al. Long-term effect of pulse crops inclusion on soil-plant nutrient dynamics in 
puddled rice (Oryza sativa L.)-wheat (Triticum aestivum L.) cropping system on an Inceptisol of Indo-Gangetic plain zone of India. Nutrient Cycling in Agroecosystem 2014;100:95-110.

18. Kakraliya SK, Singh U, Bohra A, Choudhary KK, Kumar $\mathrm{S}$, Meena RS et al. "Nitrogen and legumes: a metaanalysis," in Legumes for Soil Health and Sustainable Management, eds R. Meena, A. Das, G. Yadav, and R. Lal (Singapore: Springer) 2018a,277-314. doi: 10.1007/978-981-13-0253-4_9

19. Kakraliya SK, Jat HS, Singh I, Sapkota TK, Singh LK, Sutaliya JM et al. Performance of portfolios of climate smart agriculture practices in a rice-wheat system of western Indo-Gangetic plains. Agricultural Water Management 2018;202:122-133.

20. Kumar R, Singh G, Walia SS. Long-term effect of manures and fertilizers on rice yield and soil fertility status in rice-wheat system. Environment and Ecology 2000;18(3):546-549.

21. Kumar S. Effect of varying moisture regimes in zero-till wheat succeeding moong and sorghum and simulation of crop growth models, Ph.D. Thesis, Department of Agronomy, CCS HAU, Hisar 2008.

22. Ladha JK, Kumar V, Alam MM, Sharma S, Gathala M, Chandna $\mathrm{P}$ et al. Integrating crop and resource management technologies for enhanced productivity, profitability, and sustainability. In: Ladha, J.K., Singh, Y., Erenstein, O., Hardy, B. (Eds.), Integrated Crop and Resource Management in the Rice-Wheat System of South Asia. International Rice Research Institute, Los Baños, Philippines 2014,69-108p.

23. Lentz RD, Bjorneberg DL. Polyacrylamide and straw residue effects on irrigation furrow erosion and infiltration. J. Soil Water Conserv 2003;58:312-319.

24. Mukherjee D. Effect of tillage practices and fertility levels on the performance of Wheat (Triticum aestivum) under mid hill condition of West Bengal. Indian Journal of Agricultural Sciences 2008;78(12):1038-1041.

25. Pinheiro EFM, Pereira MG, Anjos LHC. Aggregate distribution and soil organic matter under different tillage systems for vegetable crops in a Red Lat 2004.

26. Powlson DS, Bhogal A, Chambers BJ, Coleman K, Macdonald AJ. The potential to increase soil carbon stocks through reduced tillage or organic material additions in England and Wales: A case study. Agricultural Ecology and Environment 2012;146:23-33.

27. Sheoran OP, Tonk DS, Kaushik LS, Hasija RC, Pannu RS. In: Hooda, D.S., Hasija, R.C. (Eds.), Statistical Software Package for Agricultural Research Workers. Recent Advances in Information Theory, Statistics \& Computer Applications. Department of Mathematics Statistics, CCS HAU, Hisar 1998,139-143p.

28. Singh J, Singh KP, Yadav SS, Yadav JS. Effect of preceding crops and fertility levels on wheat (Triticum aestivum) in light-textured soil. Indian Journal of Agronomy 2003;48:86-88.

29. Singh M, Singh VP, Reddy KS. Effect of integrated use of fertilizer nitrogen and farmyard manure or green manure on transformation of $\mathrm{N}, \mathrm{K}$ and $\mathrm{S}$, and productivity of rice-wheat system on a vertisol. Journal of the Indian Society of Soil Science 2001;49:430-435.

30. Swaminathan MS, Bhavani RV. Food production \& availability- Essential prerequisites for sustainable food security. Indian J Med Res 2013;138:383-91.
31. Thiagalingam K, Gould N, Watson P. Effect of tillage on rainfed maize and soybean yield and the nitrogen fertilizer requirements for maize. Soil \&Tillage Research 1991;19:47-54. 